\title{
HUMAN SEX IDENTIFICATION FROM FRONTAL AND MAXILLARY AIR SINUSES USING CT SCAN
}

\author{
Soheir A. Mohamed, Esam M. Abdullah, Ahmed M. Said, Alzahraa E. Ahmed \\ Department of Forensic Medicine and Clinical Toxicology, Faculty of Medicine, Sohag \\ University, Sohag, Egypt
}

Corresponding Author: Alzahaa E.Ahmed

E-mail:elzahraa.esmail89@gmail.com

Postal address: Department of Forensic Medicine and Clinical Toxicology, Faculty of Medicine , Sohag University, Nasr city, Sohag, Egypt.

\begin{abstract}
Background:Gender determination is one of the important parameters in forensic identification. Study of anthropometric characters is of fundamental importance to solve problems related to such cases. Paranasal sinuses and particularly the frontal sinuses have been utilized for this purpose. The unique nature and irregular shape of the paranasal air sinuses make them suitable for this purpose. In cases of mass disaster and criminal cases, paranasal sinuses remain intact even if the skull and other bones are badly blemished.Objectives: The present study was designed to determine sex by the use of frontal and maxillary air sinuses dimensions from CT scans of paranasal sinuses. Methods: The present work included 100 adult patients (50 males and 50 females). The measurements of the length and width of the maxillary and frontal air sinuses were done using CT scan on DICOM images using Electronic Caliper inbuilt in the DICOM viewer software. Results: Right frontal air sinus width was the most specific (specificity $86 \%$ ) and right frontal air sinus length was the most sensitive (sensitivity 94\%) measure to discriminate between both genders. ROC analysis indicated that the highest sensitivity rate was obtained for left maxillary air sinus length (sensitivity 100\%) and the highest specificity rate was obtained for right maxillary air sinus length (specificity 100\%). The right frontal air sinus length was the best discriminate variable between genders with overall accuracy of $80 \%$ in females and $92 \%$ in males. The maxillary air sinus length was the best predictor of gender in males and females with accuracy (100\% in females and 98\% in males).Conclusion:The mean values of frontal and maxillary air sinuses widths and lengths for both right and left sides were statistically higher in males in comparison to females. The mean values of right side frontal and maxillary air sinuses lengths and widths were higher than those of the left side in males and females. The left maxillary air sinus length is the most specific and sensitive parameter to predict gender.
\end{abstract}

KEYWORDS: Sex identification, maxillary, frontal air sinus, dimensions, CT scan.

\section{INTRODUCTION}

Identification is the most important issue in criminal cases and in forensic concerns. Depending on available bones and their condition, a number of methods with different reliability are available for the identification of unknown remains. In personal and sex identification, DNA profile gives the most accurate results(Yuwanati et al., 2012).

Linear dimensions used in anthropometric or odontometric, can be used for sex determination because of their simplicity, reliability, and inexpensiveness (Yuwanati et al., 2012 and Narang et al., 2015).

Many parts as sella-turcica, mastoid air cells, paranasal air sinuses and specially the frontal air sinuses have been used in identification of human remains that are highly damaged, burnt or decomposed. This is due to its shape which is irregular and specific with respect to every individual just like finger prints (Mary et al., 2009).In cases of mass 
disasters, the skull and other bones are severly damaged, but it has been reported that maxillary air sinuses remain intact (Attia et al., 2012 and Kanthem et al., 2015).

Frontal air sinues are paired air filled cavities present posterior to the superciliary cavities in the frontal bone and each frontal air sinus ends by opening into corresponding middle meatus via the infundibulum (Attia et al., 2012 and Kanthem et al., 2015). They are not present at birth and starts its development after birth during the second year. Frontal air sinus is not visible in radiographs till five years after birth.It is widely accepted that the development of the frontal air sinus is completed by 20 years of age. It remains constant till the chambers enlarged more as a result of bone resorption during advanced age (Cristiane et al.,2004 and Tatlisumak et al., 2008).

Maxillary sinuses are paired air filed cavities present in the maxillary bone. The apex of the sinuses reach into the zygomatic process occupying the zygomatic bone and the alveolar process of the first, second and third molar teeth form its floor and the roots of canines may rise the sinuses or may penetrate their floor. (Chandra et al., 2014).

\section{AIM OF THE WORK}

The present study aims to compare between the use of frontal and maxillary sinus dimensions on cephalometric radiographs for sex determination. The height and width of each sinus will be measured by using DICOM viewer software.

\section{SUBJECTS AND METHOD}

\section{1-Subjects:-}

The present work included 100 adult subjects 50 were males and 50 were females .Their ages were between 20 and 45 years old . as the maxillary air sinus dimensions stabilize beyond the second decade of age and to avoid effect of hormonal changes in menopausal females.The present work included patients who complained of headaches and admitted to the radiology clinic in Sohag university hospital, with the pre-diagnosis of sinusitis, but their CT scans didn't show any abnormal findings. When CT was done, the patients were in prone position and they didn't receive any sedatives or contrast medium agents.

\section{Inclusion criteria:}

*Age between 20 and 45 years

*Normal CT scan of paranasal sinuses.

\section{Exclusion criteria:}

*Facial trauma.

* Maxillary or frontal air sinus fractures.

*Congenital anomalies or

developmental abnormalities.

* Any pathological abnormality of maxillary or frontal air sinus.

\section{2-Apparatus:}

All the patients were examined on Toshiba 16 (16 slice) Spiral Multi Detector Computed Tomography Scanner at radiology department in Sohag university hospital, using an exposure of $100 \mathrm{~K} . \mathrm{V}, 240 \mathrm{~mA}$ and radiation dose $302.4 \mathrm{mGY}$. The measurements of the length and width maxillary air sinus and frontal air sinus were done directly on laptop (Toshiba Satellite C855D-S5351) on DICOM images using Electronic Caliper inbuilt in the DICOM viewer software.

\section{3-METHOD}

a-The length of the frontal air sinus was measured on reconstructed image at sagittal view. It was the largest distance cranio-caudal from the most cranial point to the most caudal point (Figure1) (Hamed et al., 2014).

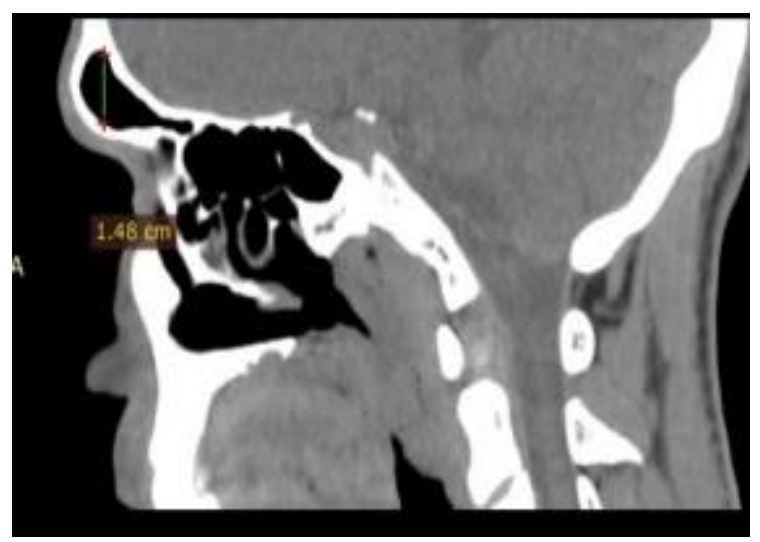

Figure(1): The length of frontal air sinus 
b-The Width of the frontal air sinus was measured on reconstructed image at coronal view. It was defined as the largest distance perpendicular from the medial wall of the sinus to the outermost point of lateral wall of frontal air sinus (Figure 2) (Hamed et al., 2014).

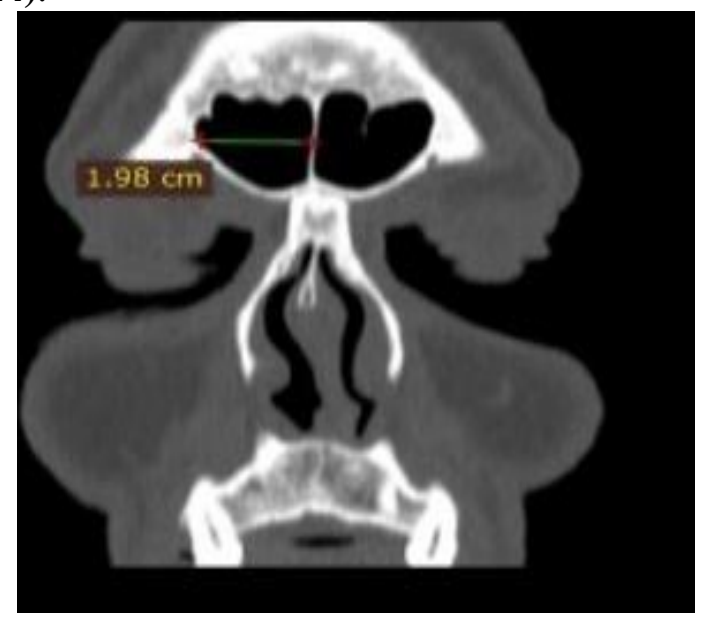

Figure(2): The width of frontal air sinus

c-The length of the maxillary air sinus was measured on reconstructed image at coronal view. It was the largest distance cranio-caudal from the most cranial point to the most caudal point (Figure3) (Ahmed et al., 2013).

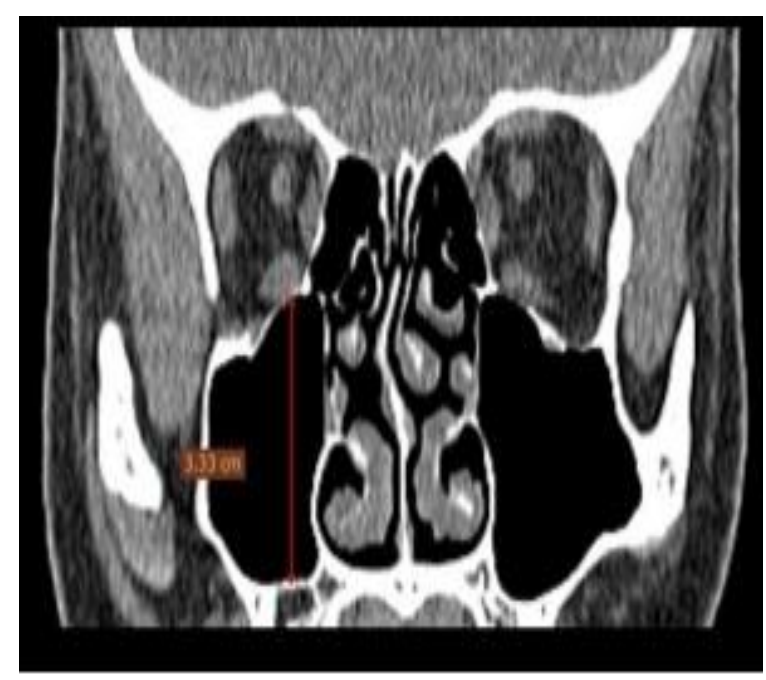

Figure(3): The length of maxillary air sinus

d- The width of the maxillary air sinus was measured on reconstructed image at axial view. It was defined as the longest distance perpendicular from the medial wall of the sinus to the outermost point of lateral wall of the lateral process of maxillary sinus (Figur4) (Jehan et al ., 2014).

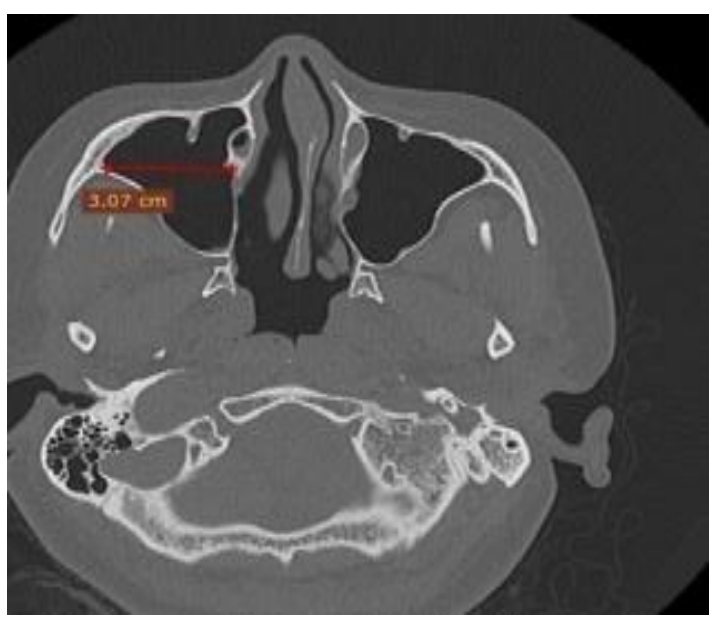

Figure(4): The width of maxillary air sinus

4- Statistical study:- Data was analyzed using SPSS computer program version 17.0.Quantitative data was expressed as means \pm standard deviation, median and range. Qualitative data was expressed as number and percentage. The data were tested for normality using Shapiro-Wilk test. The nonparametric Mann-Whitney test, and Wilcoxon Signed Ranks test were used for data which wasn't normally distributed.

Receiver operating characteristic (ROC) curve was constructed for optimum cut off points of the studied measures in predicting male gender and the area under the ROC curve value with $95 \%$ CI (confidence interval) was calculated. Optimal cut-off values were determined; sensitivity, specificity, Youden index were calculated.

Cohen's kappa and its significance were calculated to assess the agreement of predictions of the studied measurements with the actual gender of the participants. A $5 \%$ level was chosen as a level of significance in all statistical tests used in the study. The analysis used benchmark scale that Landis and Koch proposing the extent of agreement can be qualified as "Poor" $(\mathrm{k}<0)$, "Slight" $(\mathrm{k}=0-0.20)$, "Fair" $(\mathrm{k}=0.21$ 0.40), "“ Moderate" $(\mathrm{k}=0.41-0.60)$, 
"Substantial" (k=0.61-0.80), and "Almost Perfect" $(\mathrm{k}=0.81-1.00)$ depending on the magnitude of kapp (Boiculese et al.,2009).

\section{RESULTS}

This study included 100 subjects (50 male and 50 females) between 20-45 years old. There is no significant difference between males and females as regard age. The mean value of age was $(34.48 \pm 5.24)$ for males and (35.48 \pm 5.39$)$ for females (Table 1). The value of the mean of the width of right frontal air sinus was higher in males $(1.78 \pm 0.39)$ than females $(1.19 \pm 0.31)$. The value of the mean of the length of right frontal air sinuses Also the value of the mean of width of left frontal air sinuses was higher in males $(1.55 \pm 0.45)$ than females $(1.04 \pm$ 0 . 27).The value of the mean of the left frontal air sinus length was $(1.89 \pm 0.37)$ in males which was higher than females $(1.24 \pm$ 0.32). Table (2)

The value of the mean of width of the right maxillary air sinus was higher in males $(2.41 \pm 0.38)$ than females $(2.06 \pm 0.38)$.the mean value of the length of the right maxillary air sinus was higher in males $(3.56 \pm 0.43)$ than females (2.65 \pm 0.22$)$. Table (2).

Also width of the left maxillary air sinus has higher mean value in males $(2.28 \pm$ $0.41)$ than females $(1.84 \pm 0.39)$. The value of mean of the length of left maxillary air sinus was higher in males $(3.46 \pm 0.38)$ than females (2.44 \pm 0.22$)$. Table (2).

By using Receiver Operator Characteristic analysis, The value of the area under the ROC curve measured for sinus length and width of both right and left frontal and maxillary air sinuses.

Youden index was significant for all measures (significant index if more than50\%) (Table 3).

For the left frontal air sinus width the value of the area under the ROC curve was calculated (AUC $=0.801, \mathrm{p}<0.001,95 \%$ CI $\rightarrow 0.786-0.928$ ). The data demonstrated a great precision regarding sex prediction. The study results indicated a cut-off value for left frontal air sinus width of 1.06 regarding sex determination which corresponded to $92 \%$ sensitivity and $70 \%$ specificity. Thus, values less than 1.06 indicated with great probability that the participant is female (Table 3).

As regard the left frontal air sinus length the value of the area under the ROC curve was calculated (AUC $=0.890, \mathrm{p}<0.001$, $95 \%$ CI $\rightarrow 0.812: 0.944)$. The data demonstrated a great precision regarding sex prediction. The study results indicated a cutoff value for left frontal air sinus length of 1.39 regarding sex determination which corresponded to $92 \%$ sensitivity and $80 \%$ specificity. Thus, values less than 1.39 indicated with great probability that the participant is female (Table 3).

Table (1): Comparison between males and females regarding frontal and maxillary air sinuses measures as regard age. $(\mathrm{N} .=100)$.

\begin{tabular}{|l|c|c|c|}
\hline \multicolumn{1}{|c|}{ Variables } & $\begin{array}{c}\text { Males } \\
(\mathbf{N = 5 0})\end{array}$ & $\begin{array}{c}\text { Females } \\
(\mathbf{N}=50)\end{array}$ & P-value \\
\hline $\begin{array}{l}\text { Age } \\
\text { Mean } \pm \text { SD }\end{array}$ & $\mathbf{3 4 . 4 8} \pm \mathbf{5 . 2 4 3 2}(\mathbf{2 8}-\mathbf{4 4})$ & $\begin{array}{c}35.48 \pm 5.39 \\
\mathbf{3 5}(\mathbf{2 5}-\mathbf{4 5})\end{array}$ & $\mathbf{0 . 1 9 9}$ \\
Median (Range) & & \\
\hline
\end{tabular}

P-value is calculated by Mann-Whitney $U$ test

P-value $<0.05$ is statistically significant 
Table (2) : Comparison between males and females regarding frontal and maxillary air sinuses measures $(\mathrm{N} .=100)$

\begin{tabular}{|c|c|c|c|}
\hline Variables & $\begin{array}{l}\text { Males } \\
(\mathrm{N}=50)\end{array}$ & $\begin{array}{c}\text { Females } \\
(\mathbf{N}=50)\end{array}$ & P-value \\
\hline $\begin{array}{l}\text { Right frontal width } \\
\text { Mean } \pm \text { SD } \\
\text { Median (Range) }\end{array}$ & $\begin{array}{c}1.78 \pm 0.39 \\
1.77(1.06-2.67)\end{array}$ & $\begin{array}{c}1.19 \pm 0.31 \\
1.16(0.64-1.88)\end{array}$ & $<0.001$ \\
\hline $\begin{array}{l}\text { Right frontal length } \\
\text { Mean } \pm \text { SD } \\
\text { Median (Range) }\end{array}$ & $\begin{array}{c}2.21 \pm 0.42 \\
2.13(1.3-3.06)\end{array}$ & $\begin{array}{c}1.47 \pm 0.32 \\
1.45(0.91-2.06)\end{array}$ & $<0.001$ \\
\hline $\begin{array}{l}\text { Left frontal width } \\
\text { Mean } \pm \text { SD } \\
\text { Median (Range) }\end{array}$ & $\begin{array}{c}1.55 \pm 0.45 \\
1.44(1-2.54)\end{array}$ & $\begin{array}{c}1.04 \pm 0.27 \\
0.99(0.53-1.74)\end{array}$ & $<0.001$ \\
\hline $\begin{array}{l}\text { Left frontal length } \\
\text { Mean } \pm \text { SD } \\
\text { Median (Range) }\end{array}$ & $\begin{array}{c}1.89 \pm 0.37 \\
1.93(1.07-2.85)\end{array}$ & $\begin{array}{c}1.24 \pm 0.32 \\
1.19(0.59-1.99)\end{array}$ & $<0.001$ \\
\hline $\begin{array}{l}\text { Right maxillary width } \\
\text { Mean } \pm \text { SD } \\
\text { Median (Range) }\end{array}$ & $\begin{array}{c}2.41 \pm 0.38 \\
2.47(1.02-3.25)\end{array}$ & $\begin{array}{c}2.06 \pm 0.38 \\
2.01(1.51-2.83)\end{array}$ & $<0.001$ \\
\hline $\begin{array}{l}\text { Right maxillary length } \\
\text { Mean } \pm \text { SD } \\
\text { Median (Range) }\end{array}$ & $\begin{array}{c}3.56 \pm 0.43 \\
3.47(2.83-4.89)\end{array}$ & $\begin{array}{c}2.65 \pm 0.22 \\
2.72(2.24-2.97)\end{array}$ & $<0.001$ \\
\hline $\begin{array}{l}\text { Left maxillary width } \\
\text { Mean } \pm \text { SD } \\
\text { Median (Range) }\end{array}$ & $\begin{array}{c}2.28 \pm 0.41 \\
2.15(1.53-3.34)\end{array}$ & $\begin{array}{c}1.84 \pm 0.39 \\
1.95(1.04-2.44)\end{array}$ & $<0.001$ \\
\hline $\begin{array}{l}\text { Left maxillary length } \\
\text { Mean } \pm \text { SD } \\
\text { Median (Range) }\end{array}$ & $\begin{array}{c}3.46 \pm 0.38 \\
3.49(2.78-4.73)\end{array}$ & $\begin{array}{c}2.44 \pm 0.22 \\
2.47(2.04-2.83)\end{array}$ & $<0.001$ \\
\hline
\end{tabular}

P-value is calculated by Mann-Whitney $U$ test

P-value $<0.05$ is statistically significant 
For the right frontal air sinus width the value of the area under the ROC curve was calculated (AUC $=0.879, \mathrm{p}<0.001,95 \% \mathrm{CI}$ $\rightarrow 0.799-0.936)$. The data demonstrated a great precision regarding sex prediction. The study results indicated a cut-off value for right frontal air sinus width of 1.48 regarding sex determination which corresponded to $82 \%$ sensitivity and $86 \%$ specificity. Thus, values less than 1.48 indicated with great probability that the participant is female (Table 3).

As regard the right frontal air sinus length the value of the area under the ROC curve calculated (AUC $=0.926, \quad \mathrm{p}<0.001$, 95\%CI: $\rightarrow$ 0.856-0.969) demonstrated a great precision regarding sex prediction. The study results indicated a cut-off value for left frontal air sinus length of 1.76 regarding sex determination which corresponded to $94 \%$ sensitivity and $82 \%$ specificity. Thus, values less than 1.76 indicated with great probability that the participant is female (Table3).

For the left maxillary air sinus width the value of the area under ROC curve was calculated (AUC $=0.771, \mathrm{p}<0.001,95 \% \mathrm{CI}$ $\rightarrow 0.676-0.849$ ). The data demonstrated a great precision regarding sex prediction. The study results indicated a cut-off value for left frontal air sinus length of 1.99 regarding sex determination which corresponded to $76 \%$ sensitivity and $66 \%$ specificity. Thus, values less than 1.99 indicated with great probability that the participant is female (Table3).

As regard the left maxillary air sinus length the value of the area under the ROC curve was calculated (AUC $=0.998, \mathrm{p}<0.001$, $95 \%$ CI $\rightarrow 0.960-1)$. The data demonstrated a great precision regarding sex prediction. The study results indicated a cut-off value for left frontal air sinus length of 2.83 regarding sex determination which corresponded to $98 \%$ sensitivity and $100 \%$ specificity. Thus, values less than 2,83 indicated with great probability that the participant is female (Table3).

As regard the right maxillary air sinus width revealed that the value of the area under the ROC curve was calculated (AUC $=0.749 \quad \mathrm{p}<0.001, \quad 95 \% \mathrm{CI}$ : AUC $\rightarrow$ 0.653-0.831). The data demonstrated a great precision regarding sex prediction. The study results indicated a cut-off value for left frontal sinus length of 2.2 regarding sex determination which corresponded to $78 \%$ sensitivity and $64 \%$ specificity. Thus, values less than 2,2 indicated with great probability that the participant is female (Table 3).

The results of the right maxillary air sinus length were as follow: the value of the area under the ROC curve calculated $(\mathrm{AUC}=0.993, \mathrm{p}<0.001,95 \% \mathrm{CI}: \rightarrow 0.950-1)$ demonstrated a great precision regarding sex prediction. The study results indicated a cutoff value for left frontal sinus length of 2.97 regarding sex determination which corresponded to $96 \%$ sensitivity and $100 \%$ specificity. Thus, values less than 2,83 indicated with great probability that the participant is female (Table 3).

The concordance of the results for the left frontal air sinus width was significant, the kappa coefficient was $(\mathrm{k}=0.62, \mathrm{p}<0.001)$ indicating a moderate agreement degree. $70 \%$ of females \& $92 \%$ of males were correctly predicted using left frontal sinus width (Table 4).

For the left frontal air sinus length the kappa coefficient was $(\mathrm{k}=0.72, \mathrm{P}<0.001)$ indicating a substantial agreement degree. $80 \%$ of females \& $92 \%$ of males were correctly predicted using left frontal air sinus length..

As regard the right frontal air sinus width the kappa coefficient was $(k=0.68$, $\mathrm{p}<0.001)$ indicating a moderate agreement degree. $86 \%$ of females \& $82 \%$ of males were correctly predicted using right frontal sinus width (table 4).

For the left maxillary air sinus width the kappa coefficient was $(\mathrm{k}=0.42, \mathrm{p}<0.001)$ indicating a moderate agreement degree $66 \%$ of females $\$ 76 \%$ of males were correctly predicted using left maxillary air sinus width. (table 4). 
For the left maxillary air sinus length was significant, the kappa coefficient $(k=0.98, p<0.001)$ indicating a perfect agreement degree $99 \%$ of females $\& 98 \%$ of males were correctly predicted using Lt maxillary sinus length.

For the Rt maxillary sinus width the kappa coefficient was $(\mathrm{k}=0.42, \mathrm{p}<0.001)$ indicating a moderate agreement degree. $64 \%$ of Females $\$ 78 \%$ of males were correctly predicted using Rt maxillary sinus width.

Table (3): Receiver operating characteristic (ROC) analysis of thestudied measures of frontal and maxillary air sinuses of both males and females for optimum cut off points inpredicting sex.

\begin{tabular}{|c|c|c|c|c|c|c|c|}
\hline Measure & Cutoff & AUC & $95 \% \mathrm{CI}$ & $\begin{array}{c}\text { Sensitivity } \\
(\%)\end{array}$ & $\begin{array}{c}\text { Specificity } \\
(\%)\end{array}$ & $\begin{array}{l}\text { Youden } \\
\text { index } \\
(\%)\end{array}$ & P-value \\
\hline Left frontal width & $>1.06$ & 0.801 & $\begin{array}{c}0.786 \text { to } \\
0.928\end{array}$ & 92 & 70 & 62 & $<0.001 *$ \\
\hline Left frontal length & $>1.39$ & 0.890 & $\begin{array}{c}0.812 \text { to } \\
0.944\end{array}$ & 92 & 80 & 72 & $<0.001 *$ \\
\hline Right frontal width & $>1.48$ & 0.879 & $\begin{array}{c}0.799 \text { to } \\
0.936\end{array}$ & 82 & 86 & 68 & $<0.001 *$ \\
\hline Right frontal length & $>1.76$ & 0.926 & $\begin{array}{c}0.856 \text { to } \\
0.969\end{array}$ & 94 & 82 & 76 & $<0.001 *$ \\
\hline $\begin{array}{l}\text { Left maxillary } \\
\text { width }\end{array}$ & $>1.99$ & 0.771 & $\begin{array}{c}0.676 \text { to } \\
0.849\end{array}$ & 76 & 66 & 52 & $<0.001 *$ \\
\hline $\begin{array}{l}\text { Left maxillary } \\
\text { length }\end{array}$ & $>2.83$ & 0.998 & 0.960 to 1 & 98 & 100 & 98 & $<0.001 *$ \\
\hline $\begin{array}{l}\text { Right maxillary } \\
\text { width }\end{array}$ & $>2.2$ & 0.749 & $\begin{array}{c}0.653 \text { to } \\
0.831 \\
\end{array}$ & 78 & 64 & 52 & $<0.001 *$ \\
\hline $\begin{array}{l}\text { Right maxillary } \\
\text { length }\end{array}$ & $>2.97$ & 0.993 & 0.950 to 1 & 96 & 100 & 58.2 & $<0.001 *$ \\
\hline
\end{tabular}

$\mathrm{Cl}=$ confidence interval

AUC =area under the ROC curve

Youden indexsignificant if value more than $50 \%$

$\mathbf{P}$-value is calculated by Mann-Whitney $U$ test

P-value $<0.05$ is statistically significant
As regard the Rt maxillary sinus length was significant, the kappa coefficient $(\mathrm{k}=0.96, \mathrm{p}<0.001)$ indicating a perfect agreement degree $100 \%$ of females\&96\% of males were correctly predicted using Rt maxillary sinus length. (Table 4). 
Table (4): The degree of predictability of the measured dimensions of the right and left frontal and maxillary air sinues regarding sex determination.

\begin{tabular}{|c|c|c|c|c|}
\hline \multirow[t]{2}{*}{ Measure } & \multicolumn{2}{|c|}{$\begin{array}{l}\text { Percentage of Correct } \\
\text { Predictions }\end{array}$} & \multirow[t]{2}{*}{ Kappa $(\mathbf{K})$} & \multirow[t]{2}{*}{ P-value } \\
\hline & Female & Male & & \\
\hline Left frontal width & $70 \%$ & $92 \%$ & 0.62 & $<0.001$ \\
\hline Left frontal length & $80 \%$ & $92 \%$ & 0.72 & $<0.001$ \\
\hline Right frontal width & $86 \%$ & $82 \%$ & 0.68 & $<0.001$ \\
\hline Right frontal length & $82 \%$ & $94 \%$ & 0.76 & $<0.001$ \\
\hline Left maxillary width & $66 \%$ & $76 \%$ & 0.42 & $<0.001$ \\
\hline Left maxillary length & $100 \%$ & $98 \%$ & 0.98 & $<0.001$ \\
\hline Right maxillary width & $64 \%$ & $78 \%$ & 0.42 & $<0.001$ \\
\hline Right maxillary length & $100 \%$ & $96 \%$ & 0.96 & $<0.001$ \\
\hline
\end{tabular}

\section{DISCUSSION}

Age distribution in the present study was statistically homogenous between both males and females, thus the difference observed between males and females was not bIased by age distribution.

At the present study there were significant higher values in the mean of measures of frontal air sinus at both sides right and left in males than those in females. The current results were in agreement with Lee et al. (2010), who compared between males and females using CT scan and founded that almost all dimensions of frontal air sinuses were higher in males. The same for, Mathur et al. (2013), they founded that males had significantly larger size of frontal air sinuses (width and length) in comparison to females..

Also the present study findings were in consistent with the findings founded by Ponde et al. (2005) who concluded that males had significant higher antero-posterior and transverse dimensions of the frontal air sinuses.

Tambawala et al. (2016) and Kanthem et al. (2015) demonstrated that there were higher significant values for both the left and right maxillary air sinus as regard the length, and width dimensions in male group. In agreement to the present work, some previous studies founded that males had significantly wider maxillary air sinuses when compared with females.(Sarma et al., (2014) Uthman et al,. (2011) and Sahlstrand et al., (2011), the recorded difference between males and females as regard maxillary air sinus measurements could be due to the fact that there is difference between males and females as regard skull size as whole, which still present in modern humans.

In contrast to the present study, Baweja et al. (2013) and Uthman et al. (2011) founded that the mean value of the width of 
maxillary air sinuses showed no statistical difference between males and females.

The differences between the studies may be due to using different sizes of the samples, inclusion criteria, methods of measurements, regions or points of reference ,or different analysis types. Moreover, differences can appear due to many factors, but especially the differences in group ancestry, as stature, size of skeleton, body build, environmental factors and pneumatization process of sinuses in different age and sex groups, also presence or absence of teeth can be afactor (Sharan et al., 2008).

In the present study, for each measurement the Receiver Operator Characteristic analysis (ROC) was utilized for validity assessment. For every dimension, calculation of the cut-off value between sensitivity and specificity showed that for frontal air sinus measures the right frontal air sinus width was the most specific (specificity $86 \%$ ) and right frontal air sinus length was the most sensitive (sensitivity 94\%) measure to discriminate between both genders. (Table 3).

In partial agreement with the present study, Hamed et al. (2014), the Receiver Operator Characteristic analysis (ROC) was utilized for validity determination of tested measurements, When determined the cut-off value for each measurement between sensitivity and specificity, it was founded that right frontal air sinus width has more sensitivity and specificity than other variables of frontal air sinus to differentiate between genders.

In contrast to the present work, (Uthman et al. (2011), reported that between cut-off values, the left frontal air sinus height was with highest sensitivity and considered the best differentiating measurement followed by the right frontal air sinus width. This could be explained by differences in nutritional, racial features and geographic location (Patil et al., 2005).
The present work showed that among all frontal air sinus measurements the right frontal air sinus was the best differentiating measurement between males and females with accuracy degree of $80 \%$ in females and 92\% in males (Table 4).

Hamed et al. (2014), founded that the right frontal air sinus antero-posterior measurement was the best measurement for differentiation between males and females with accuracy degree of $67.0 \%$. This percentage $(67 \%)$ of accurate gender discrimination is well, but not ideal and limits the use of measurements in clinical practice.

However the percent may rise when utilized together with other measurements for sex discrimination as reported by Uthman et al. (2011), who founded higher degree of accuracy for frontal air sinus dimensions to differentiate between males and females, which was $76.9 \%$. When the skull measures added to measures of the frontal air sinus, the degree of accuracy for sex determination increases to $85.9 \%$.

Camargo et al. (2007), utilized the frontal air sinus dimensions for sex identification and founded that the degree of accuracy was $79.7 \%$.

In the current study, the results of ROC analysis showed that left maxillary air sinus length has highest sensitivity (sensitivity $100 \%$ ) and the right maxillary air sinus length has the highest specificity rate (specificity $100 \%$ ) . (Table 3).

Uthman et al. (2011) founded that the right maxillary air sinus width has the highest sensitivity and the highest specificity rates. This difference may be related to difference in race.

The present study founded that the length of maxillary air sinus was the best measure in gender prediction in males and females with accuracy degree $(100 \%$ in females and $98 \%$ in males (Table 4). 
In harmony with the present study Teke et al. (2007) reported that the degree of accuracy of gender discrimination of $69.4 \%$ in females and $69.2 \%$ in males. Uthman et al. (2011) showed that in males $74.4 \%$ of maxillary air sinuses and in females $73.3 \%$ of maxillary air sinuses were identified correctly and the all percent of correct determination of gender from maxillary air sinuses was $73.9 \%$.

In contrast to the present study Chandra et al. (2014), concluded that the maxillary air sinus was accurate and reliable in gender determination using morphometric measures (area and perimeter), through lateral cephalogram. The percent of correct and accurate prediction was found to be $70.8 \%$ in males and $62.5 \%$ in females and that showed accuracy of male identification with maxillary air sinus is more accurate than in females.

\section{CONCLUSION}

1-The mean values of frontal and maxillary air sinuses widths and lengths for both right and left sides were statistically higher in males when compared with females.

2- The mean values of right side frontal and maxillary air sinuses lengths and widths were higher than those of the left side in males and females.

3- Through the current study, we founded that the mean value of the left maxillary air sinus length is the most specific and sensitive one to predict gender.

This study can be useful to predict sex from the measurements of the paranasal sinuses which highlights the practical medicolegal implications of the results.

\section{RECOMENDATIONS}

*Further studies should use larger number sample with different age groups to compare between the accuracy of using frontal and maxillary air sinus dimensions in different age groups.

\section{REFERENCES}

-Ahmed ,A.m.; Yusof ,A. and Hassan ,R.(2013): Three dimensional computed tomography (3D-CT): A study of maxillary sinus in Malays, Canadian Journal of Basic and Applied Sciences, vol.1:125-134.

Attia, A., El-Badrawy, A. and Shebel, H.(2012): Gender identification from maxillary sinus using multi-detector computed tomography, Mansoura J. Forensic Med. Clin. Toxicol. 1: 17-28.

Baweja, S.; Dixit, A. and Baweja, S.(2013): Study of age related changes of maxillary air sinus from its anteroposterior, transverse and vertical dimensions using computerized tomographic (CT) scan. IJBR, 4:21-25.

Boiculese, L.V.;Dimitriu, G. and Moscalu, M.(2009). Nearest neighbor classification with improved weighted dissimilarity measure. Proceedings of the Romanian Academy Series AMathematics Physics Technical Sciences Information Science, Ed. Academiei Romane, 10: 205-213.

Camargo, J.R.;Daruge,E.; Prado, F.B.; Caria,p.H.;Alves,M.C.; Silva, R.F. and Daruge,E.(2007): Sinus morphology in radiographs of Brazilian subjects and its forensic importance, Braz.J. Morphol. Sci,24:239-243.

Chandra, S.; Devi, P.; Taneja, N.; Sah, K.and Kaur, N. (2014): Forensic importance of maxillary sinus in gender determination: A morphometric analysis from Western Uttar Pradesh, India, European Journal of General Dentistry, 3:51-53. 
Cristiane, R. R.; Nader, N. (2004): Anatomo-radiological and morphometrical study of the frontal sinus in humans,Braz J Morphol Sci, 6 : 21-53.

Hamed, S. S.; El-Badrawy, A. M. and Fattah, S. A. (2014): Gender identification from frontal sinus using multi-detector computed tomography, Journal of Forensic Radiology and Imaging, 2:117-120.

Jehan ,M.; Bhadkaria ,V.;Trivedi ,A. and Sharma,S.K.(2014): Sexual dimorphism of bizygomatic distance \& maxillary sinus using CT scan,IOSR Journal of Dental and Medical Sciences. Vol.13:91-95.

Kanthem, R.;Guttikonda, V.; Yeluri, S. and Kumari, G. (2015): Sex determination using maxillary sinus, Journal of Forensic Dental Sciences, 7:163-164.

Lee, M.K.; Sakai, O. and Spiegel, J.H.(2010):CT measurement of the frontal sinus-Gender differences and implications for frontal cranioplasty, J. Craniomaxillo facial Surg, 38:494-500.

Mary, C.; Matthew, M .; Scott, I. and Fairgrieve,A. (2009): A new digital method for the objective comparison of frontal sinuses for identification, $\mathrm{J}$ Forensic Sci, 54:761-771

Mathur, H.;Mathur,A.;Ahmed, J.; Khorate, M. and Tripathi, P.(2013): Conventional frontal sinus imaging in identification of sex, In population of Udaipur city, India,J. Med.Sci.Clin.Res, 1:33-37.

Narang, R. S.; Manchanda, A. S. and Singh, B.(2015): Sex assessment by molar odontometrics in North Indian population, J Forensic Dent Sci,54: 7-8.

Patil, K. and Mody, R. N. (2005): Determination of sex by discriminant function analysis and stature by regression analysis: a lateral cephalometric study, Forensic. Sci, Int. 147:175-180.

Ponde, J.M.; Andrade, R.N.; Via, J.M.; Metzger, P. and Teles, A.C.(2005): Anatomical variations of the frontal sinus, Int. J. Morphol, 803-808.

Sahlstrand-Johnson, P.; Jannert, M.and Strombeck, A. and Abul-kasim, A.(2011): Computed tomography measurements of different dimensions of maxillary and frontal sinuses, BMC Med Imaging, 11:1-7.

Sharan, A. and Madjar, D.(2008): Maxillary sinus pneumatization following extractions: a radiographic study, Int $\mathrm{J}$ Oral and Maxillofacial Implants, 23:48-56.

Sharma ,S.K.; Jehan, M. and Kumar, A.(2014): Measurements of maxillary sinus volume and dimensions by computed tomography scan for gender determination, JASI, 63(1)::36-42.

Tambawala, S. S.; Karjodkar, F. R.; Sansare, K. and Prakash, N.(2016): Sexual dimorphism of maxillary sinus using cone beam computed tomography, Egyptian Journal of Forensic Sciences, 6:120-125.

Tatlisumak, E.; Yilmaz, O.G.; Asirdizer, M.; Aslan, A.; Ozyurt, B.and Bayindir, P.(2008):CT study on maophometry of frontal sinus, Clin Anat, 93: 21-287.

Teke, H.Y.; Duran, S.;Canturk, N. and Canturk, G. (2007): Determination of gender by measuring the size of the maxillary sinuses in CT scans, Surg Radiol Anat, 29:9-13.

Uthman, A. T.; Al-Rawi, N. H.; AlNaaimi, A. S. and Al-Timimi, J. F.(2011): Evaluation of Maxillary sinus dimensions in gender determination using helical CT scanning, Journal of Forensic Sciences, 56:403-408. 
Yuwanati, M; Karia, A. and Yuwanati, M.( 2012): Canine tooth dimorphism :An adjunct for establishing sex identity, J Forensic Dent Sci , 3:4-80. 


\section{الملخص العربي}

تحديد الجنس البشري من الجيوب الأنفية الهوائية الأمامية وجيوب الفك العلوي بإستخدام الأشعة المقطعية إئائ

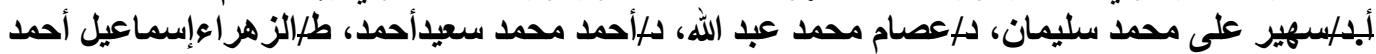

$$
\text { قسم الطب الشرعي والسموم الأكلينكية، كلية الطب - جامعة سوهام مداج }
$$

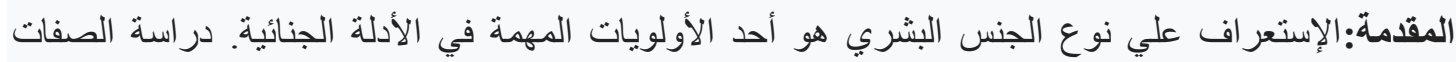
الأنثروبومترية ذات أهمية أساسية لحل المشكلات المتعلقة بهذه الحالات. الجيوب الأنفية وخاصة الجيوب الأنفية

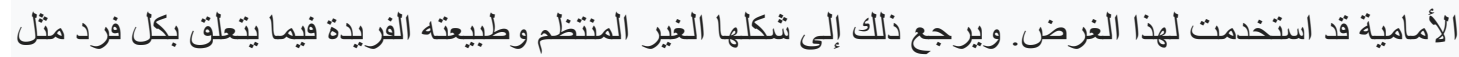

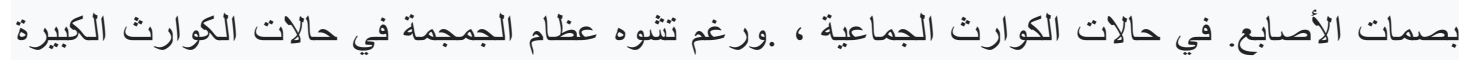

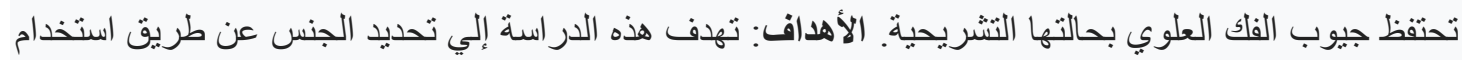
أبعاد الجيوب الأنفية الأمامية وجيوب الفك العلوي بإستخدام الأشعة المقطعية علي الجيوب الأنفية لتحديد الجنس.

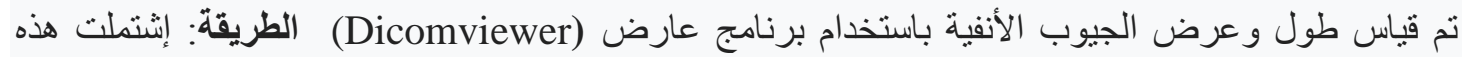

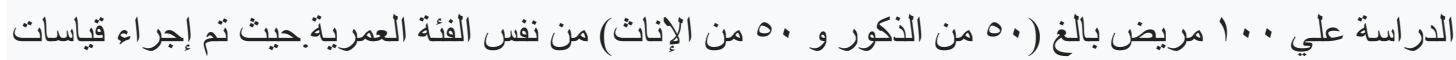

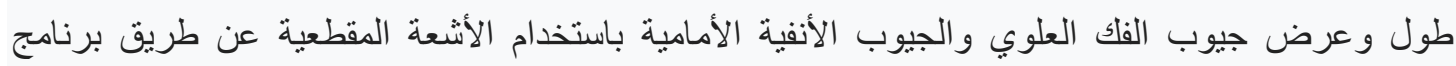
عرض( DICOM )باستخدام (Electronic Caliper).

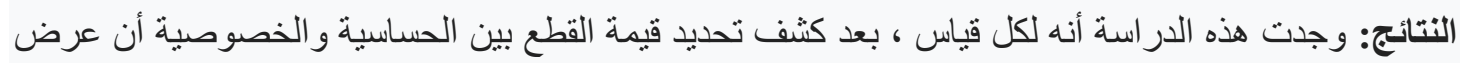

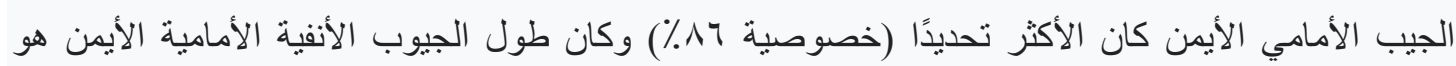

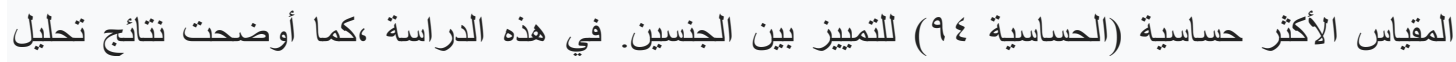
الإحصائي ROC أنه نم الحصول على أعلى معدل حساسية لطول الجيب الجيبي الفكي العلوي الأيسر (حساسية

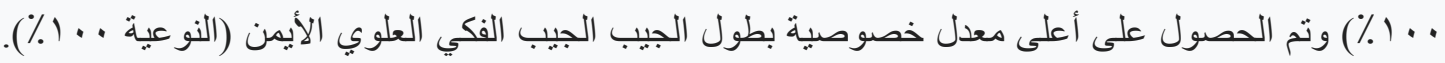

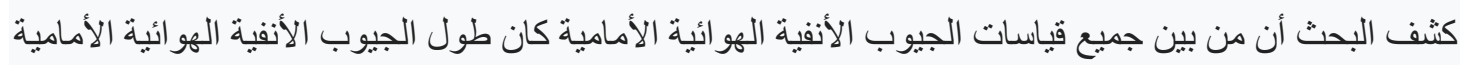

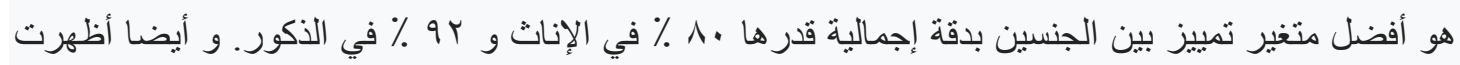

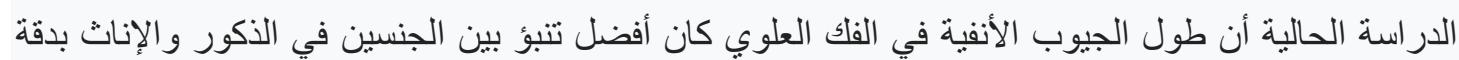

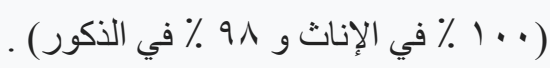

الاستنتاج: 1 ــمتوسط القيم لعرض الجيوب الأو في الأنفية الأمامية والفكية العلوية وأطو الها لكلا الجانبين الأيمن

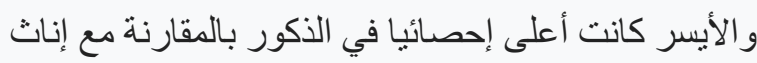

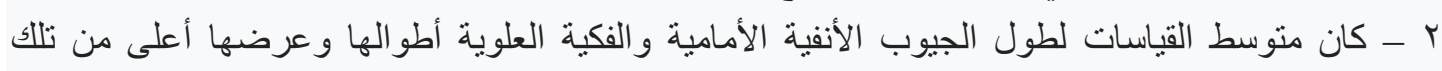

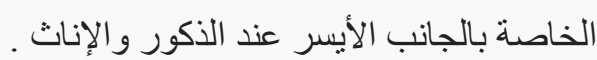
بـأخير ا استنتجت الدرانبة الابسر أن القيمة المنوسطة لطول الإناث الجيب الفكي العلوي الأيسر هي الأكثر تحديدًا وحساسية للتنبؤ بنوع الجنس التن 